\title{
EFFECTS OF HEATING TEMPERATURE AND $\beta$-CAROTENE ON QUALITY AND FATTY ACIDS COMPOSITION OF VEGETABLE OILS
}

\author{
FLAVIA POP ${ }^{a, *}$, CRINA PAȘCU ${ }^{a}$
}

\begin{abstract}
The purpose of the study was to investigate the effects of temperature and $\beta$-carotene addition on the quality parameters of corn and palm oils subjected to heating. Vegetable oils and $0.005 \% \beta$-caroten additivated oils were heated at varying temperatures $\left(100,130,160,190\right.$ and $220^{\circ} \mathrm{C}$ for 30 minutes) to follow quality alterations. Peroxide value, total polar compounds, refractive index value, iodine value and fatty acids composition were determined to measure the degree of oxidative rancidity. Peroxide value was significantly $(p<0.001)$ influenced by the type of oil, additivation and heating temperature. Palm oil with added antioxidant showed the smallest increase in polar compounds during the heat treatment. Corn oil fatty acids profile was rich in oleic (C18:1), arachidonic (C20:4), eicosenoic (C20:1), and linoleic (C18:2) fatty acids, followed by alphalinolenic (C18:3) and palmitoleic (C16:1) acids. Polyunsaturated fatty acids and monounsaturated fatty acids content decreased during heat treatment. Statistical analysis of the data revealed that the development of rancidity in vegetable oils subjected to heating was significantly $(p<0.01)$ reduced by the addition of $\beta$-carotene in concentration of $0.005 \%$.
\end{abstract}

Keywords: corn oil, palm oil, heating, fatty acids profile, peroxide index, total polar compounds

\section{INTRODUCTION}

Vegetable oils are essential ingredients in every single kitchen. Frying is delivering products with desirable sensory properties such as a crispy texture, golden crust, and unique fried food flavours in a short period of time [1].

a Technical University of Cluj-Napoca, North University Center of Baia Mare, Chemistry and Biology Department, 76A Victoriei Str., 430122, Baia Mare, Romania

Corresponding author: flavia_maries@yahoo.com 
Vegetable oils are an important source of liposoluble vitamins and essential fatty acids, which are necessary in the formation of cell membranes and in maintaining their operation. Fatty acids participate in the regulation of cholesterol metabolism and are the precursors of the hormones involved in wound healing, reducing of inflammation and blood clotting. Vegetable food oils are used for many purposes. In the countries with warm climate are used very much for cooking. In Western countries they are used in processed form, the most common product being margarine. Much of the vegetable oils are used to prepare meals, salads and ice cream [2].

Corn oil is extracted from the germ of corn, its main use is in cooking, where its high smoke point makes refined corn oil a valuable frying oil. It is also a key ingredient in some margarines and is generally less expensive than most other types of vegetable oils. It contains compounds that may promote heart health, such as phytosterols, vitamin E and linoleic acid [3].

The highly saturated nature of palm oil renders it solid at room temperature, making it a cheap substitute for butter or hydrogenated vegetable oils in uses where solid fat is desirable, such as the making of pastry dough and baked goods. The health concerns related to trans fats in hydrogenated vegetable oils may have contributed to the increasing use of palm oil in the food industry [4].

Thermal oxidation of oils occurs as a self-oxidation reaction, through the formation of free radicals. In the first stage, the reaction is initiated by the loss of a proton and the formation of an alkyl radical $(R \cdot)$. In the propagation step, the radical binds oxygen and form a peroxy radical (R-O-O-). Termination of the reaction involves the recombination of radicals with the formation of stable compounds such as: hydroperoxides, epoxies, epidioxides, hydroperoxyepidioxides, etc. The autooxidation process of oils is accelerated by the following factors: temperature, heavy metals, the presence of oxygen, the fatty acids degree of unsaturation, the absence of self-oxidation inhibitors like natural or added antioxidants [5-7].

The presence of antioxidants in frying fats can extend both the fry-life of the fats and the shelf-life of the fried products. A number of studies focused on the positive effects of the addition of plant extracts to frying fats and oils: oregano, rosemary, sage, tea, lavender and thyme [8, 9, 10, 11, 12]. Also, it has been reported that tocopherols show a rapid loss at frying temperatures due to their degradation, but $\alpha$-tocopherol is less stable at high temperature than $\delta$-tocopherol, while $\beta$ - and $\gamma$-tocopherols degrade at an intermediate rate [13]. Zeb and Murkovic have studied the thermal stability of corn oil fortified with $\beta$-carotene and reported the degradation of $\beta$-carotene during accelerated thermal oxidation [14, 15]. 
Several studies report quality degradation of vegetable oils during heating, fatty acids degradation, reduction in bioactive compounds and properties, pigments destruction, sensorial changes, and color modifications, as well as physical and rheological changes [16-20].

The purpose of this research was to investigate the effect of temperature $\left(100,130,160,190\right.$ and $220^{\circ} \mathrm{C}$ for 30 minutes) and $\beta$-carotene addition on corn and palm oils by analysing peroxide value, total polar compounds, refractive index value, iodine value and fatty acids content.

\section{RESULTS AND DISCUSSION}

Peroxide value, total polar compounds, refractive index value, iodine value and fatty acids profile were determined in order to asses the effect of heating temperature and $\beta$-carotene addition on corn and palm oils quality.

Peroxide value is a measure of primary lipid oxidation, indicating the amount of peroxides formed during oil oxidation. The products of lipid oxidation such as peroxides, free radicals, malonaldehyde and other cholesterol oxidation products are reported to promote coronary heart disease and atherosclerosis [5].

Unheated oils showed lower values of the peroxide index. Peroxide value was significantly $(p<0.001)$ influenced by treatments: additivation and heating temperature. In corn oil was found the highest level of peroxide value (Table 1) followed by the palm oil. Regardless of the heating temperature, the highest peroxide index level was found in non-additivated oil. In the case of corn oil, the most intensive peroxide formation was found at $190^{\circ} \mathrm{C}$, while over this temperature the decomposition was dominant. The reason of this trend may be that peroxides are not heat-resistant, and high temperature lowers their concentration. Antioxidant application had a statistically significant $(p<$ 0.01 ) effect on the peroxide index of corn and palm oil samples. The results showed that palm oil was more stable to heating, producing smaller amounts of peroxides (Table 2). The addition of $\beta$-carotene in a proportion of $0.005 \%$ significantly retarded the development of oxidation products, but antioxidant activity decreased with temperature due to an increased rate of initiation reactions.

Zeb and Murkovic, studied the thermal stability of corn oil fortified with 50-300 $\mu \mathrm{g} / \mathrm{g} \beta$-carotene using a Rancimat apparatus at $110^{\circ} \mathrm{C}$ for $14 \mathrm{~h}$. The research showed that most of the $\beta$-carotene was degraded during the first $5 \mathrm{~h}$ of the thermal oxidation and the addition of $\beta$-carotene produces significant effects $(p<0.05)$ on the peroxide index, free fatty acid values and radical scavenging activity of the corn oil [14]. 
Table 1. Changes in quality parameters of corn oil and $\beta$-carotene additivated oil during heating

\begin{tabular}{|l|c|c|c|c|c|c|c|c|}
\hline \multirow{2}{*}{$\begin{array}{l}\text { Heating } \\
\text { temperature }\end{array}$} & \multicolumn{4}{|c|}{ Corn oil } & \multicolumn{3}{c|}{$\mathbf{0 . 0 0 5 \%} \boldsymbol{\beta}$-Carotene additivated oil } \\
\cline { 2 - 9 } & PV & TPC & RIV & IV & PV & TPC & RIV & IV \\
\hline Unheated & $2.07^{\mathrm{a}}$ & $2.5^{\mathrm{a}}$ & $1.4847^{\mathrm{a}}$ & $99.5^{\mathrm{a}}$ & $2.05^{\mathrm{a}}$ & $2.5^{\mathrm{a}}$ & $1.4848^{\mathrm{a}}$ & $99.5^{\mathrm{a}}$ \\
\hline $100^{\circ} \mathrm{C}$ & $2.93^{\mathrm{b}}$ & $6.7^{\mathrm{c}}$ & $1.4839^{\mathrm{a}}$ & $98.4^{\mathrm{a}}$ & $2.61^{\mathrm{b}}$ & $6.0^{\mathrm{c}}$ & $1.4841^{\mathrm{a}}$ & $99.1^{\mathrm{a}}$ \\
\hline $130^{\circ} \mathrm{C}$ & $4.74^{\mathrm{c}}$ & $10.6^{\mathrm{e}}$ & $1.4828^{\mathrm{b}}$ & $97.1^{\mathrm{b}}$ & $4.03^{\mathrm{bc}}$ & $8.2^{\mathrm{d}}$ & $1.4835^{\mathrm{a}}$ & $98.4^{\mathrm{ab}}$ \\
\hline $160^{\circ} \mathrm{C}$ & $6.82^{\mathrm{d}}$ & $16.8^{\mathrm{f}}$ & $1.4791^{\mathrm{bc}}$ & $94.2^{\mathrm{bc}}$ & $6.12^{\mathrm{c}}$ & $14.5^{\mathrm{e}}$ & $1.4806^{\mathrm{b}}$ & $96.7^{\mathrm{b}}$ \\
\hline $190^{\circ} \mathrm{C}$ & $9.14^{\mathrm{e}}$ & $20.4^{\mathrm{g}}$ & $1.4759^{\mathrm{c}}$ & $91.3^{\mathrm{c}}$ & $8.55^{\mathrm{d}}$ & $18.7^{\mathrm{f}}$ & $1.4784^{\mathrm{bc}}$ & $93.8^{\mathrm{bc}}$ \\
\hline $220^{\circ} \mathrm{C}$ & $8.45^{\mathrm{de}}$ & $25.3^{\mathrm{h}}$ & $1.4721^{\mathrm{cd}}$ & $90.1^{\mathrm{d}}$ & $9.36^{\mathrm{e}}$ & $21.4^{\mathrm{g}}$ & $1.4752^{\mathrm{c}}$ & $92.1^{\mathrm{c}}$ \\
\hline$p$ & $<0.001$ & $<0.001$ & $<0.05$ & $<0.01$ & $<0.01$ & $<0.01$ & $<0.05$ & $<0.01$ \\
\hline
\end{tabular}

a) PV, peroxide value (meq $\mathrm{O}_{2} / \mathrm{kg}$ ); TPC, total polar compounds (\%); RIV, refractive index value (refractometric degrees); IV, iodine value $\left(\mathrm{g} \mathrm{I}_{2} / 100 \mathrm{~g}\right)$.

b) Values are expressed as mean.

c) Different letters in the same column indicate statistically significant differences (Tukey's test $p<0.05)$.

d) Significant differences are denoted by asterisks: ${ }^{*} p<0.05$; ${ }^{* *} p<0.01$; ${ }^{* * *} p<0.001 ; p \geq 0.05$, non-significant.

The degradation of $\beta$-carotene in corn oil during accelerated thermal oxidation was also observed [15]. The study showed that $\beta$-carotene promoted oxidation of triacylglycerols especially at longer exposure times and the researchers identified new classes of oxidized triacylglycerols in corn oil, which were epidioxy bis-hydroperoxides and hydroxy bis-hydroperoxides.

Several authors have reported an increase in peroxide index of oils during heating or frying [21, 22]. Filip et al., investigated the influence of two natural antioxidants on trans fatty acids formation during heat treatment of sunflower oil at $180^{\circ} \mathrm{C}$ for 120 hours. The study showed that the addition of rosemary extract and lutein significantly reduced the formation of trans fatty acids, with lutein suppressing the formation of trans fatty acids to a greater extent than the rosemary extract. The researchers also observed that the natural antioxidants tested proved to be useful additives to frying oils; they did not only prevent oxidation, but they also prevented trans isomerisation in the early stages of heat treatment, and reduced the formation of polar compounds [23].

Polar compounds include all oxidized triglycerides, dimerized triglycerides, free fatty acids, monoglycerides, diglycerides, sterols, antifoamers, hydrogenation catalyst residues and soaps formed during repeated heating of oils [24].

Total polar compounds indicate the state of oil deterioration and in all samples it was noticed that oils with added $\beta$-carotene were more stable. 
According to some researchers the degradation of oils can be measured by polar compounds, which indicate the breakdown of triglycerides. During frying process the polar compounds accumulate on the surface of frying pan and foods. It can be imagined that the most poisonous components exist in the polar compounds of oil [25].

If the total polar compounds exceed more than $24 \%$, the oil should be disposed according to Banu et al. [24]. It is observed from Table 1, that the total polar compound values exceeded $24 \%$ when corn oil was heated at $220^{\circ} \mathrm{C}$. Polar compounds are found to be $21.4 \%$ for additivated corn oil and $19.6 \%$ for additivated palm oil subjected to heating at $220^{\circ} \mathrm{C}$. The results indicate that $\beta$-carotene was an effective antioxidant in delaying oxidation for these edible oils.

The initial values of total polar compounds were not significantly different between the oil samples, indicating that the added antioxidant had no effects on the initial contents of polar compounds in the oil. With the heat treatment, there were noticed increases in the polar compounds in all of the samples, with and without $\beta$-carotene and the highest final content of polar compounds was noticed in the corn oil sample. $\beta$-Carotene had significant effects $(p<0.01)$ on the total polar compounds and palm oil with added antioxidant showed the smallest increase in polar compounds during the heat treatment (Table 2). In both oils, the polar compounds were significantly reduced $(p<0.01)$ by the addition of $\beta$-carotene. Significantly less polar compounds were formed in samples with added antioxidant at all stages of the heat treatment.

Table 2. Changes in quality parameters of palm oil and $\beta$-carotene additivated oil during heatin

\begin{tabular}{|l|c|c|c|c|c|c|c|c|}
\hline \multirow{2}{*}{$\begin{array}{l}\text { Heating } \\
\text { temperature }\end{array}$} & \multicolumn{4}{|c|}{ Palm oil } & \multicolumn{3}{c|}{$\mathbf{0 . 0 0 5 \%} \boldsymbol{\beta}$-Carotene additivated oil } \\
\cline { 2 - 9 } & PV & TPC & RIV & IV & PV & TPC & RIV & IV \\
\hline Unheated & $1.56^{\mathrm{a}}$ & $2.1^{\mathrm{a}}$ & $1.4657^{\mathrm{a}}$ & $79.1^{\mathrm{a}}$ & $1.54^{\mathrm{a}}$ & $2.0^{\mathrm{a}}$ & $1.4658^{\mathrm{a}}$ & $79.2^{\mathrm{a}}$ \\
\hline $100^{\circ} \mathrm{C}$ & $2.28^{\mathrm{b}}$ & $5.6^{\mathrm{c}}$ & $1.4648^{\mathrm{a}}$ & $78.5^{\mathrm{a}}$ & $2.10^{\mathrm{b}}$ & $4.7^{\mathrm{c}}$ & $1.4653^{\mathrm{a}}$ & $78.8^{\mathrm{a}}$ \\
\hline $130^{\circ} \mathrm{C}$ & $3.93^{\mathrm{c}}$ & $9.8^{\mathrm{d}}$ & $1.4641^{\mathrm{b}}$ & $77.7^{\mathrm{b}}$ & $3.16^{\mathrm{bc}}$ & $7.9^{\mathrm{cd}}$ & $1.4644^{\mathrm{a}}$ & $78.1^{\mathrm{b} \mathrm{b}}$ \\
\hline $160^{\circ} \mathrm{C}$ & $5.71^{\mathrm{cd}}$ & $14.3^{\mathrm{e}}$ & $1.4609^{\mathrm{c}}$ & $75.1^{\mathrm{c}}$ & $4.96^{\mathrm{c}}$ & $12.8^{\mathrm{d}}$ & $1.4619^{\mathrm{b}}$ & $76.2^{\mathrm{b}}$ \\
\hline $190^{\circ} \mathrm{C}$ & $7.69^{\mathrm{d}}$ & $18.4^{\mathrm{f}}$ & $1.4587^{\mathrm{cd}}$ & $72.5^{\mathrm{cd}}$ & $6.85^{\mathrm{cd}}$ & $16.5^{\mathrm{e}}$ & $1.4594^{\mathrm{bc}}$ & $73.7^{\mathrm{bc}}$ \\
\hline $220^{\circ} \mathrm{C}$ & $9.62^{\mathrm{e}}$ & $22.7^{\mathrm{g}}$ & $1.4569^{\mathrm{d}}$ & $70.8^{\mathrm{d}}$ & $8.97^{\mathrm{d}}$ & $19.6^{\mathrm{f}}$ & $1.4577^{\mathrm{c}}$ & $71.9^{\mathrm{c}}$ \\
\hline$p$ & $<0.001$ & $<0.001$ & $<0.05$ & $<0.01$ & $<0.01$ & $<0.01$ & $<0.05$ & $<0.01$ \\
\hline
\end{tabular}

a) PV, peroxide value (meq $\mathrm{O}_{2} / \mathrm{kg}$ ); TPC, total polar compounds (\%); RIV, refractive index value (refractometric degrees); IV, iodine value ( $\left.\mathrm{g} \mathrm{I}_{2} / 100 \mathrm{~g}\right)$.

b) Values are expressed as mean.

c) Different letters in the same column indicate statistically significant differences (Tukey's test $p<0.05)$.

d) Significant differences are denoted by asterisks: ${ }^{*} p<0.05 ;{ }^{* *} p<0.01 ;{ }^{* * *} p<0.001 ; p \geq 0.05$, non-significant. 
Refractive index value and iodine value are measures of the degree of unsaturation of fatty acids. Corn oil presented a higher value of refractive index compared to palm oil and the values decreased significant $(p<0.05)$ with the increase in heating temperature, in samples with and without $\beta$-carotene.

lodine index values also decreased significant $(p<0.01)$ with the increase in heating temperature, as a result of the reduction in the degree of unsaturation, by the split of unsaturated fatty acids double bonds. Between the iodine index and the refractive index values, there was found a direct correlation $(r=0.97)$.

Fatty acids represent the main constitutes of the saponifiable fraction of vegetable oils, the fatty acids profile for unheated and oils subjected to heating at $220^{\circ} \mathrm{C}$ is presented.

Corn oil fatty acids profile was dominant in oleic acid (C18:1), with levels exceeding $29 \%$, followed by arachidonic acid (C20:4) with near $17 \%$, eicosenoic acid (C20:1) with 10\%, palmitic acid (C16:0) with 9.1\%, linoleic acid (C18:2) with $8.7 \%$ and alphalinolenic acid (C18:3) containing approximately $7.6 \%$ (Fig. 1). The palmitoleic (C16:1) and vaccenic acid $\left(\mathrm{C} 18: 1_{i}\right)$ amounts were also important ( 6.5 respectively $5.8 \%$ ).

Palm oil fatty acids profile was rich in palmitic (C16:0), stearic (C18:0), oleic (C18:1), vaccenic $\left(C 18: 1_{i}\right)$ and palmitoleic $(C 16: 1)$ fatty acids, followed by myristic (C14:0) and linolenic (C18:2) acids (Fig. 3). Corn oil was predominantly polyunsaturated, while palm oil was mainly monounsaturated.

Heating at a temperature of $220^{\circ} \mathrm{C}$, inflicted changes in fatty acids profile of both oils. Analyzing the fatty acids by their common nature, the most affected fraction was the polyunsaturated fatty acids (PUFA), directly related with their higher number of double bonds, with higher susceptibility to oxidation (Fig. 2, Fig. 4). With high heating temperature, PUFA content decreased with $14 \%$ in corn oil, and around $9 \%$ in palm oil. The heat treatment of oils induces modifications of unsaturated fatty acids, these may undergo isomerization from cis to trans form. The fatty acid profile of the heated fats changed as a result of cyclization, polymerization and hydrolytic, oxidative and other chemical reactions promoted by heat treatment.

Stojanovski et al. studied the influence of heat treatment on fatty acids composition in poultry meat after frying in different types and combinations of animal and vegetable fats. The researchers observed that during the thermal processing of the poultry in lard, the content of C18:1 increased from $45.84 \%$ to $49.05 \%$, while C18:0 decreased from $10.18 \%$ to $7.45 \%, \mathrm{C} 16: 0$ also decreased from $29.55 \%$ to $27.45 \%$. The changes that occur in fatty acid composition of fats after thermal processing of the meat were minimal and did not show statistical significance [26]. 


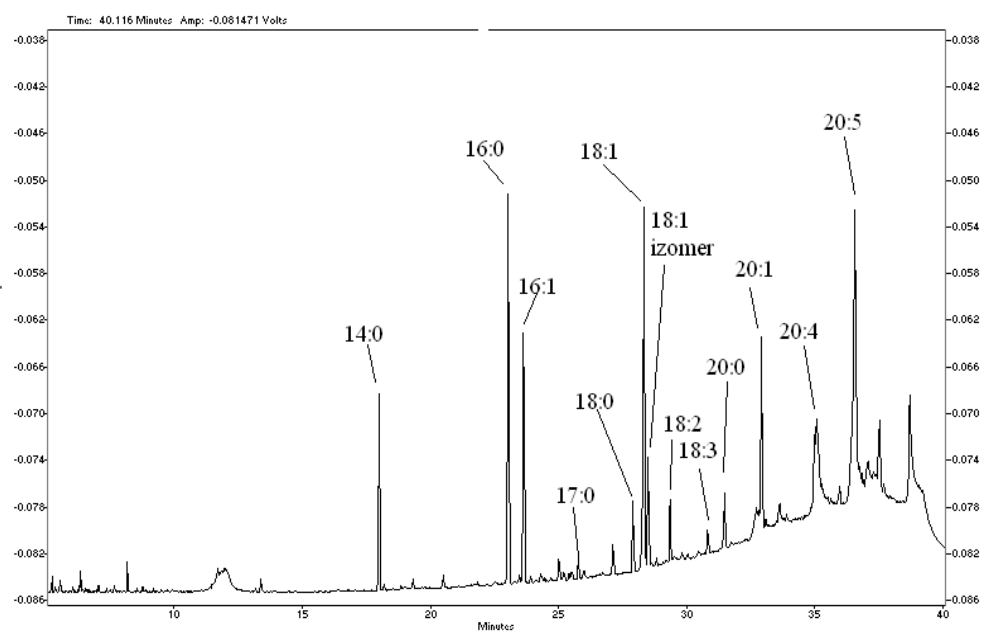

Figure 1. Gas chromatogram of unheated corn oil

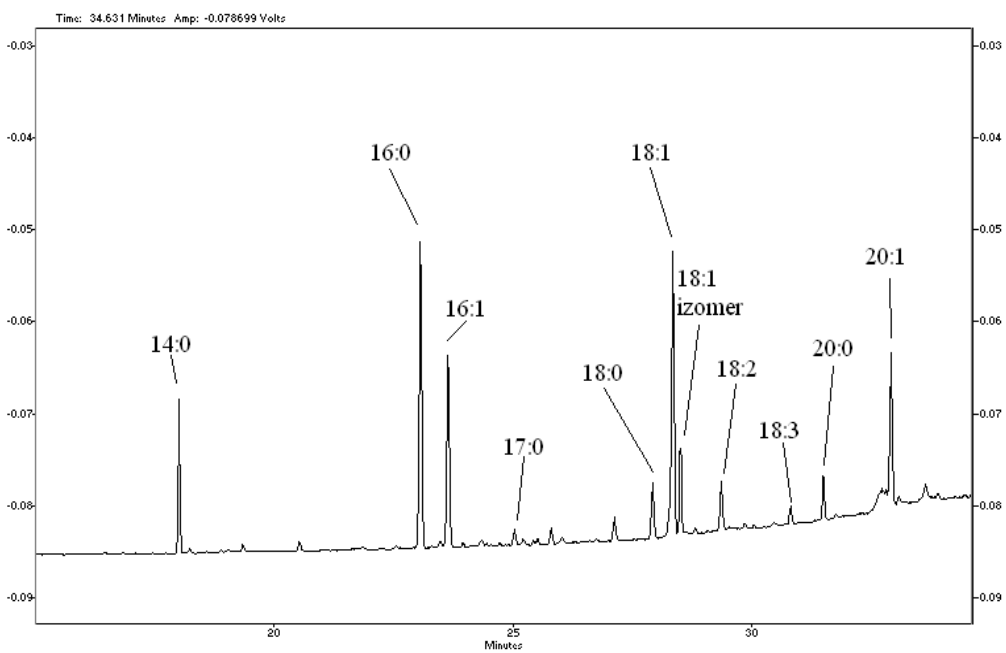

Figure 2. Gas chromatogram of corn oil subjected to heating at $220^{\circ} \mathrm{C}$ 
FLAVIA POP, CRINA PAȘCU

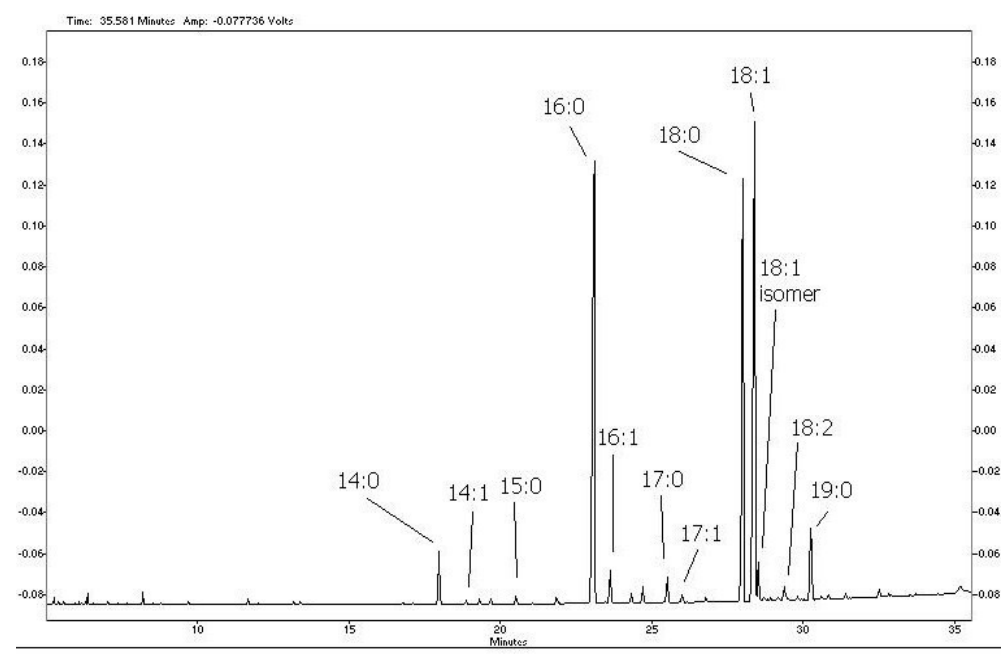

Figure 3. Gas chromatogram of unheated palm oil

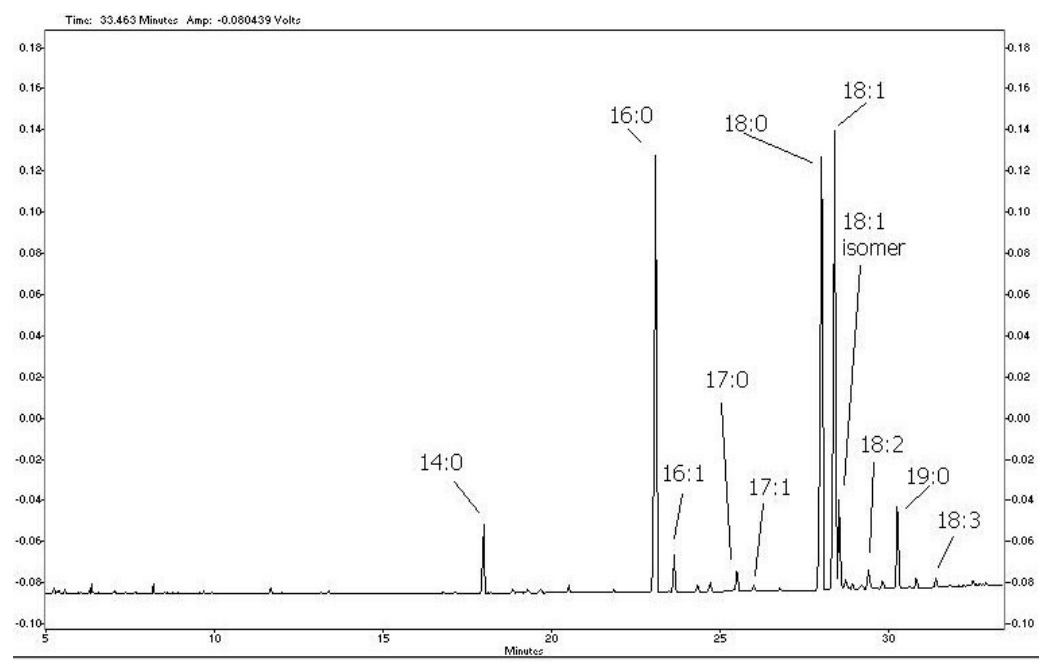

Figure 4. Gas chromatogram of palm oil subjected to heating at $220^{\circ} \mathrm{C}$ 


\section{CONCLUSIONS}

Lipid oxidation in vegetable oils varied with the heating temperature and antioxidant addition. Unheated oils showed lower values of the peroxide index. In corn oil was found the highest level of peroxide value followed by the palm oil. Regardless of the heating temperature, the highest peroxide index level was found in non-additivated oil. Corn oil was more unstable at heat treatment, producing higher amounts of hydroperoxides.

$\beta$-Carotene had significant effects on the total polar compounds and palm oil with added antioxidant showed the smallest increase in polar compounds during the heat treatment. In both oils, the polar compounds were significantly reduced by the addition of $\beta$-carotene.

Heating inflicted changes in fatty acids profile of both oils, the most affected fraction was the polyunsaturated fatty acids, directly related with their higher number of double bonds, with higher susceptibility to oxidation.

Statistical analysis of the data revealed that the development of rancidity in vegetable oils subjected to heating at varying temperatures was significantly reduced by the addition of $\beta$-carotene in concentration of $0.005 \%$.

\section{EXPERIMENTAL SECTION}

\section{Samples}

To assess the behavior of corn and palm oils under heating conditions, commercial samples were obtained from local markets. $\beta$-Carotene was dissolved in oils in the concentration of $0.005 \%(0.005 \mathrm{~g} / 100 \mathrm{~g}$ of oil). Approximately $50 \mathrm{~mL}$ of oil were individually subjected to heating in an electric oven (FM11, Ariston, Fabriano, Italy) at $100,130,160,190$ and $220^{\circ} \mathrm{C}$ for 30 minutes. We used glass vessels with $80 \mathrm{~cm}^{2}$ of exposure area with air. The cold samples were transferred to glass tubes and kept in refrigeration until analysis. For each studied oil, one sample was used as control sample (unheated). Three replications were carried out to examine each sample. All chemicals were of analytical grade and obtained from Merck (Germany); $\beta$-carotene was purchased from Sigma (Sigma Chemicals, Shanghai, China).

\section{Physicochemical examination}

Peroxide value was determined using UV-VIS spectrophotometer (Bibby Scientific, London, UK). A test portion was dissolved in a mixture of 
chloroform/methanol $(2: 1, \mathrm{v} / \mathrm{v})$, then iron(II) chloride and ammonium thiocyanate were added. This protocol was based on the spectrophotometer determination of ferric ions $\left(\mathrm{Fe}^{3+}\right)$ derived from the oxidation of ferrous ions $\left(\mathrm{Fe}^{2+}\right)$ by hydro peroxides, in the presence of ammonium thiocyanate $\left(\mathrm{NH}_{4} \mathrm{SCN}\right)$. Thiocyanate ions $\left(\mathrm{SCN}^{-}\right)$react with $\mathrm{Fe}^{3+}$ ions to give a red-violet homogeny that can be determined spectrophotometrically; the absorbance of each solution was read at $500 \mathrm{~nm}$. To quantify PV, a calibration curve (absorbance at $500 \mathrm{~nm}$ vs. $\mathrm{Fe}^{3+}$ expressed in $\mu \mathrm{g}$ ) was constructed. Peroxide value was expressed as meq $\mathrm{O}_{2} / \mathrm{kg}$ sample [27].

The measurement of the polar compounds was carried out using a rapid method: Testo 265 , based on dielectric constant measurements. This method shows high correlations between dielectric readings using the food oil sensor compared with the percent polar compounds obtained by liquid chromatography [28].

To determine the refractive index we used the PAL-RI (Tokyo, Japan) with the following technical characteristics: field: $1,3306-1,5284$; resolution: 0.0001; accuracy: \pm 0.0003 ; measuring temperature: $5-45^{\circ} \mathrm{C}$ (resolution $1^{\circ} \mathrm{C}$ ); measuring time: $3 \mathrm{~s}$; in accordance with the requirements of EMC Directive 93/68/EEC.

lodine value was determined using Hanus method. Approximately 0.5 g sample (dissolved in $15 \mathrm{~mL} \mathrm{CCl}_{4}$ ) was mixed with $25 \mathrm{~mL}$ Hanus solution $(\mathrm{IBr})$ to halogenate the double bonds. After storing the mixture in the dark for 30 minutes, excess $\mathrm{IBr}$ was reduced to free $\mathrm{I}_{2}$ in the presence of $20 \mathrm{~mL}$ of $\mathrm{KI}$ $(100 \mathrm{~g} / \mathrm{L})$ and $100 \mathrm{~mL}$ distilled water. Free $\mathrm{I}_{2}$ was measured by titration with $24.9 \mathrm{~g} / \mathrm{L} \mathrm{Na} \mathrm{S}_{2} \mathrm{O}_{3} \cdot 5 \mathrm{H}_{2} \mathrm{O}$ using starch $(1.0 \mathrm{~g} / 100 \mathrm{~mL})$ as an indicator. lodine value was calculated as $\mathrm{g} \mathrm{I}_{2} / 100 \mathrm{~g}$ sample [27].

Fatty acids composition was determined using a Shimadzu GC-17 A gas chromatograph (Tokyo, Japan) coupled with a flame ionization detector.

To obtain methyl esters, $2 \mathrm{~mL}$ sample was introduced in a roundbottomed flask to which was added $20 \mathrm{~mL}$ of sulphuric acid methanol solution and 3 pieces of porous porcelain; a reflux cooler was fitted to the flask and it was boiled for about 60 minutes in a water bath. The content of the flask was cooled to room temperature and then was passed quantitatively in a separatory funnel using $20 \mathrm{~mL}$ of water, and the methyl esters were extracted in two stages with $20 \mathrm{~mL}$ of heptanes. The extracts were combined into another separatory funnel and washed with $20 \mathrm{~mL}$ of water until the sulphuric acid was completely removed, the removal being controlled with methyl orange. The extracts were then dehydrated by the addition of anhydrous sodium sulphate and filtered into a flask. Methyl esters were collected in 1 $\mathrm{mL}$ hexane, and $1 \mu \mathrm{L}$ sample was injected in the gas chromatograph. 
The gas chromatography column is Alltech AT-Wax, $(60 \mathrm{~m} \times 0.32 \mathrm{~mm}$ $x 0.5 \mu \mathrm{m}$ ), stationary phase (polyethylene); helium was used as a carrier gas at a pressure of $147 \mathrm{kPa}$, temperature of the injector and detector was set to $260^{\circ} \mathrm{C}$, and the oven program was the following: $70^{\circ} \mathrm{C}$ for 2 minutes, then the temperature was raised to $150^{\circ} \mathrm{C}$ with a gradient of $10^{\circ} \mathrm{C} /$ minute, a level of 3 minutes, and the temperature was raised to $235^{\circ} \mathrm{C}$ with a gradient of $4^{\circ} \mathrm{C} /$ minute. Identification and quantification of $\mathrm{FA}$ were performed by comparison with standards. Results were expressed as \% [28].

\section{Statistical analysis}

All analytical determinations were performed at least in triplicate. Values of different parameters were expressed as the mean \pm standard deviation $(X \pm S D)$. Tukey's honest significance test was carried out at a 95\% confidence level $(p<0.05)$. The Pearson's correlation $(\alpha=0.05)$ with twotailed probability values was used to estimate the strength of association between chemical parameters.

\section{ACKNOWLEDGMENTS}

This work was financial supported by Technical University of ClujNapoca in the framework of the GNaCARUT competition, research Contract no. $3015 / 2019$.

\section{REFERENCES}

1. V. K. Tyagi; A. K. Vasishtha; J. Am. Oil Chem. Soc., 1996, 73, 499-507.

2. C. A. Costa; A. S. Carlos; G. P. Gonzalez; R. P. Reis; Eur. J. Nutr., 2012, 51, 191-198.

3. S. Wang; K. A. Meckling; M. F. Marcone; Y. Kakuda; R. Tsao; J. Agric. Food Chem., 2011, 59, 960-967.

4. E. Valantina; S. Sahayararaj; A. Prema; Rasayan J. Chem., 2010, 3, 44-53.

5. Z. P. Pai; T. B. Khlebnikova; Y. V. Mattsat; V.N. Parmon; React. Kinet. Catal. Lett., 2009, 98, 1-8.

6. O. Roman; B. Heyd; B. Broyart; R. Castillo; M. N. Maillard; LWT - Food Sci. Technol., 2013, 52, 49-58.

7. A. H. Noor Armylisas; M. F. Siti Hazirah; S. K. Yeong; A. H. Hazimah; Grasas Aceites, 2017, 68, 130-136.

8. R. De Guzman; S. Haiying Tang; K. Y. S. Salley; J. Am. Oil Chem. Soc., 2009, 86, 459-467.

9. M. Wroniak; K. Krygier; M. Kaczmarczyk; Pol. J. Food Nutr. Sci., 2008, 58, 85-93. 
10. A. Biswas; A. Adhvaryu; D. G. Stevenson; B. K. Sharma; Ind. Crops Prod., 2007, 25, 1-9.

11. A. Bendini; E. Valli; L. Cerretani; E. Chiavaro; G. Lercker; J. Agric. Food Chem., 2009, 57, 1055-1063.

12. A. M. El Anany; Electron. J. Food Plants Chem., 2007, 2, 14-21.

13. S. Ernest; P. Kavitha; Int. J. Chem. Environ. Pharm. Res., 2011, 2, 111-118.

14. A. Zeb; M. Murkovic; J. Am. Oil Chem. Soc., 2013, 90, 881-889.

15. A. Zeb; M. Murkovic; Food Res. Int., 2013, 50, 534-544.

16. N. Rodrigues; R. Malheiro; S. Casal; M. C. Manzanera; Food Chem. Toxicol., 2012, 50, 2894-2902.

17. E. S. Shaker; LWT - Food Sci. Technol., 2006, 39, 883-892.

18. K. Warner; J. Agric. Food Chem., 2005, 23, 9906-9913.

19. H. Yoshida; S. Takagi; J. Sci. Food Agric., 1999, 62, 41-50.

20. F. A. Aladedunye; Eur J. Lipid Sci. Technol., 2014, 116, 688-695.

21. F. Caponio; A. Pasqualone; T. Gomes; Int. J. Food Sci. Technol., 2003, 38, 481-488.

22. F. Kreps; L. Vrbiková; S. Schmidt; S. Sekretár; O. Híreš; Eur. J. Lipid Sci. Technol., 2014, 116, 1685-1694.

23. S. Filip; J. Hribar; R. Vidrih; Eur. J. Lipid Sci. Technol., 2011, 113, 224-233.

24. M. Banu; N. Prasad; N. Siddaramaiah; Int. Food Res. J., 2016, 23, 528-537.

25. W. W. Nawar, Lipids. In: Fennema COR (ed.) Food chemistry, 3rd edn. Marcel Dekker, New York, 1996, pp. 225-234.

26. M. Stojanovski; A. Čakarova; A. Kuzelov; E. Joshevska; G. Dimitrovska; D. Tomovska; K. Bojkovska; J. Agric. Plant Sci., 2018, 16, 103-112.

27. F. Pop; Studia UBB Chemia, 2009, LIV(4), 187-193.

28. F. Pop; Studia UBB Chemia, 2018, LXIII(2), 43-52. 